\title{
Effects of continuous milking during the dry period or once daily milking in the first 4 weeks of lactation on metabolism and productivity of dairy cows
}

\author{
G. Schlamberger, ${ }^{* 1}$ S. Wiedemann, ${ }^{*}$ E. Viturro, ${ }^{*}$ H. H. D. Meyer, ${ }^{*}$ and M. Kaske† \\ *Physiology Weihenstephan, Technische Universitaet Muenchen, 85354 Freising, Germany \\ †Clinic for Cattle, University of Veterinary Medicine, 30173 Hannover, Germany
}

\begin{abstract}
The objective was to compare the effects of 3 management systems in high-yielding dairy cows on metabolic profiles and milk production. Thirty-six multiparous Brown Swiss cows were randomly assigned to 1 of 3 treatment groups $(\mathrm{n}=12$ cows/group): the control $(\mathrm{C})$ group, in which cows were dried off $56 \mathrm{~d}$ before calving and milked twice daily throughout next lactation (305 d); the once daily milking (ODM) group, in which cows were dried off $56 \mathrm{~d}$ before calving and milked once daily for the first $4 \mathrm{wk}$ of lactation and twice daily for the remaining lactation; and the continuous milking (CM) group, in which cows were milked twice daily until calving and also during the subsequent lactation. Serum glucose concentrations decreased between wk 1 and 4 exclusively in $\mathrm{C}$ cows. Serum concentrations of NEFA and BHBA in the first 4 wk of lactation were highest in $\mathrm{C}$ cows compared with ODM and CM cows. Decreased backfat thickness during early lactation and reduction of body condition score were markedly more pronounced in $\mathrm{C}$ cows compared with ODM and $\mathrm{CM}$ cows. Mean lactational milk yield of $\mathrm{C}$ cows $[11,310$ $\pm 601 \mathrm{~kg}$ of energy-corrected milk (ECM)/305 d] was approximately $16 \%$ higher compared with ODM cows $(9,531 \pm 477 \mathrm{~kg}$ of ECM/305 d) and CM cows $(9,447 \pm$ $310 \mathrm{~kg}$ of ECM/305 d). The lactation curve of CM cows compared with $\mathrm{C}$ cows was characterized by a similar time of peak yield (wk 3), a reduced peak yield, and no obvious differences in persistency. Mean percentage of milk protein was significantly higher for CM cows (3.91\%) compared with $\mathrm{C}$ cows $(3.52 \%)$. In contrast, once daily milking was accompanied by a reduced and significantly delayed peak yield (wk 8) compared with the control treatment, whereas persistency was better and milk protein $(3.79 \%)$ was higher in ODM cows than in $\mathrm{C}$ cows. In conclusion, continuous milking and once daily milking, targeting the interval before or after calving, respectively, substantially reduced the
\end{abstract}

Received October 14, 2009.

Accepted February 9, 2010.

${ }^{1}$ Corresponding author: gregor.schlamberger@wzw.tum.de metabolic challenge of fresh cows and improved milk protein percentage. Continuous milking and once daily milking increased milk protein percentage markedly; furthermore, once daily milking during the first $4 \mathrm{wk}$ of lactation improved the lactation curve.

Key words: continuous milking, once daily milking, metabolism, productivity

\section{INTRODUCTION}

The critical challenge in high-cost, high-return dairy production systems is attaining high lactational milk yield while simultaneously achieving sustainable production by maintaining an appropriate level of animal health and fertility. Producing milk with high protein percentage to meet market demands and addressing society's concerns regarding animal welfare are also priorities. Genetic selection for greater milk production is a risk factor for a variety of production diseases because increases in feed intake lag behind increases in milk production in early lactation (Ingvartsen and Andersen, 2000; Ingvartsen et al., 2003; Mulligan and Doherty, 2008). Therefore, efforts have been made to optimize housing, feeding, and management of highyielding dairy cows (Distl, 1991; Drackley, 1999; Grummer et al., 2004).

A successful transition from late pregnancy to early lactation is essential for animal health and productivity (Grant and Albright, 1995; Drackley, 1999). One way to reduce the risk of metabolic imbalance during this is time is to omit the dry period (DP; Rémond and Bonnefoy, 1997; Andersen et al., 2005). In a study by Andersen et al. (2005), plasma concentrations of glucose and insulin were higher and plasma concentrations of NEFA and BHBA were lower in cows with an omitted DP than in control cows with a conventional DP during the first 5 wk of early lactation. However, in other studies, continuous milking compromised colostrum quality (Grummer and Rastani, 2004; Caja et al., 2006) and caused a 12 to $25 \%$ decrease in milk yield during the subsequent lactation (Swanson, 1965; Rémond et al., 1992; Rémond and Bonnefoy, 1997). Therefore, it was concluded that the DP is needed to enhance secretory 
function of the mammary gland (Rémond et al., 1997; Ingvartsen et al., 2003), enabling involution, proliferation, and redifferentiation of mammary tissue (Capuco et al., 1997; Wilde et al., 1997; Capuco et al., 2003). It was previously recommended that the DP last at least 6 to $8 \mathrm{wk}$ because shorter intervals reduced milk yield in the following lactation (Schaeffer and Henderson, 1972; Coppock et al., 1974; O'Connor and Oltenacu, 1988). Conversely, it was recently established that mammary involution is completed within $25 \mathrm{~d}$, suggesting that a 30-d DP was adequate to ensure high milk production (Capuco et al., 1997; Gulay et al., 2003). Moreover, cows assigned to a shortened DP (28 d) had an improved energy status for the first $10 \mathrm{wk}$ of lactation compared with cows with a 56-d DP (Rastani et al., 2005). Primiparous cows assigned to a 35-d DP after the first lactation had lower peripheral NEFA concentrations immediately after parturition than those given a 56-d DP (Pezeshki et al., 2007). Multiparous cows with a 28-d DP had an improved energy status based on total milk production and BCS at 150 DIM (Pezeshki et al., 2008).

Another approach to reducing the metabolic challenge during early lactation is to alter milking frequency. The interval from calving to peak yield, its magnitude, and the rate of increase of milk yield per day during the first weeks of lactation are important risk factors for production diseases in early lactation (Ingvartsen and Andersen, 2000). However, the time that peak yield occurs can be influenced only slightly by the feeding regimen, but may depend more on milking frequency. In several studies, increased frequency enhanced milk yield (van der Iest and Hillerton, 1989; Rastani et al., 2007; Wall and McFadden, 2008). In contrast, in a study by Carruthers and Davis (1993), once daily milking for $2 \mathrm{wk}$ in early lactation reduced milk yield by $16 \%$ compared with twice daily milking. Although milking thrice daily for the first $28 \mathrm{~d}$ of lactation increased milk yield by $19.6 \%$ compared with once daily milking, it was accompanied by more severe losses of body weight by d 60 of lactation (Davis et al., 1999; Patton et al., 2006). Energy status was improved in cows milked once daily during the first $3 \mathrm{wk}$ of lactation (Patton et al., 2006), reducing the risk of metabolic disorders (Rauw et al., 1998).

To date, continuous milking has not been compared with once daily milking in early lactation as a way to easier cope with the metabolic challenge of high-yielding dairy cows. Thus, the objective of the present study was to compare the effects of continuous milking without DP and milking frequency during early lactation on the metabolic profile, fertility, and productivity of the subsequent lactation. The hypothesis to be tested was that metabolic profile and, as a consequence, param- eters of productivity were different among cows that were milked either continuously or once daily for the first 4 wk of lactation compared with those managed with a traditional 56-d DP and twice daily milking after calving.

\section{MATERIALS AND METHODS}

\section{Animals and Experimental Design}

The study was conducted at the research farm Veitshof of the Technische Universitaet Muenchen (Freising, Germany) from December 2006 to December 2008 using 45 multiparous Brown Swiss dairy cows.

Cows were assigned at random to 1 of 3 treatment groups. In the control group $(\mathbf{C} ; \mathrm{n}=16)$, cows were dried off $56 \mathrm{~d}$ before expected calving and milked twice daily throughout the entire lactation (305 d). Cows in the once daily milking group (ODM; $\mathrm{n}=16)$ were dried off $56 \mathrm{~d}$ before expected calving and milked only once daily for the first $4 \mathrm{wk}$ of lactation and twice daily for the remainder of lactation. Cows of the continuous milking group ( $\mathbf{C M} ; \mathrm{n}=13)$ were milked twice daily up to the day of calving and throughout the subsequent 305-d lactation (i.e., they were not dried off).

One cow from the CM group, 4 cows from the ODM group, and 4 cows from the $\mathrm{C}$ group did not finish the entire lactation; they were removed because of various health disorders. Ultimately, complete data sets (305-d lactation) for 12 cows in each treatment group were used for statistical analysis (Table 1).

\section{Housing and Feeding}

All cows were kept in a cubicle housing system fitted with rubber-coated slatted floors and bedded with wood shavings. Cows were milked in a $2 \times 2$ tandem milking parlor (GEA WestfaliaSurge GmbH, Boenen, Germany) either once (1545 h) or twice (0415 and 1545 h) daily. For drying-off (C and ODM cows only), milking was done once daily $(1545 \mathrm{~h})$ for $3 \mathrm{~d}$ and then an intramammary antibiotic treatment containing $1 \mathrm{~g}$ of cloxacillin (Orbenin, Pfizer, Berlin, Germany) was given $56 \mathrm{~d}$ before expected calving. Thereafter, $\mathrm{C}$ and ODM cows were transferred to a separate stable and fed the DP ration (Table 2). Approximately 1 wk before expected calving, all cows were moved to single calving pens bedded with barley straw. After calving, cows were moved to the lactating herd and fed the lactation diet. The CM cows were not separated from the herd during the last 2 mo of pregnancy because they were milked throughout the entire pregnancy-lactation cycle. All lactating cows were fed the partly mixed ration formulated to meet nutrient requirements, as 
Table 1. Experimental design, animals excluded from the study and reasons for removal, and animals used for statistical analysis ${ }^{1}$

\begin{tabular}{lccc}
\hline Item & C & ODM & CM \\
\hline Cows assigned to study, n $^{2}$ & 16 & 16 & 13 \\
Daily milking frequency $^{2}$ & & & \\
d -56 to 0 & dry & dry & 2 \\
d 1 to 28 & 2 & 1 & 2 \\
d 29 to 305 & 2 & 2 & 2 \\
Cows removed from study, n & 4 & 4 & 1 \\
Downer cow syndrome & $1(4)^{3}$ & $1(1)$ & \\
Severe injuries & $1(29)$ & $1(48)$ & $1(106)$ \\
Lameness $_{\text {Mastitis }}$ & $1(194)$ & $1(159)$ & \\
Abortion & $1(239)$ & $1(137)$ & 12 \\
Cows with complete data sets, n & 12 & 12 & $8,664 \pm 336$ \\
${\text { Previous energy-corrected 305-d milk yield, }{ }^{4} \mathrm{~kg}}_{\text {Parity }^{4}}$ & $8,826 \pm 377$ & $8,725 \pm 360$ & $3.3 \pm 2.1$ \\
\hline
\end{tabular}

${ }^{1} \mathrm{C}=$ control group: cows were dried off $56 \mathrm{~d}$ before calving and milked twice daily throughout next lactation (305 d; $\mathrm{n}=12$ ); ODM = once daily milking group: cows were dried off $56 \mathrm{~d}$ before calving and milked once daily for the first $4 \mathrm{wk}$ of lactation and twice daily for the remaining lactation $(\mathrm{n}=12)$; $\mathrm{CM}=$ continuous milking group: cows were milked twice daily until calving and also during the subsequent lactation $(\mathrm{n}=12)$.

${ }^{2}$ Numbers indicate days relative to calving.

${ }^{3}$ Values in parentheses represent days of lactation when cows were removed from the study.

${ }^{4}$ Mean \pm SEM.

indicated by GfE (2007) (Table 2), and had ad libitum access to fresh water.

In addition, hay was fed immediately after milking $(0600 \mathrm{~h})$. The partly mixed ration, formulated on the basis of a milk yield of $22 \mathrm{~kg} / \mathrm{d}$, was delivered once daily $(0700 \mathrm{~h})$ and was intended to provide ad libitum intake ( $>5 \%$ residual feed). Cows producing more than $22 \mathrm{~kg} / \mathrm{d}$ were fed additional concentrates $(0.5 \mathrm{~kg}$ of concentrate $/ \mathrm{kg}$ of milk, maximal $9 \mathrm{~kg} / \mathrm{d}$; Raiffeisen Kraftfutterwerke Süd, Würzburg, Germany) in feeding stations.

\section{Health and Occurrence of Diseases}

Health status was assessed daily. Retained fetal membranes, periparturient paresis, primary ketosis, mastitis, and lameness occurred during the study. Nine cows were removed from the study (Table 1) because they were severely affected with the following disorders: downer cow syndrome $(\mathrm{n}=2 ; 1 \mathrm{C}$ and $1 \mathrm{ODM}$ cow $)$, severe injuries ( $\mathrm{n}=2 ; 1 \mathrm{C}$ and $1 \mathrm{ODM}$ cow), lameness $(\mathrm{n}=3 ; 1 \mathrm{C}, 1 \mathrm{ODM}$, and $1 \mathrm{CM}$ cow $)$, mastitis $(\mathrm{n}=1$; 1 ODM cow $)$, or abortion ( $\mathrm{n}=1 ; 1 \mathrm{C}$ cow $)$.

\section{Records and Sampling}

Milk yield was measured twice daily with electronic milk meters (Metatron P21, GEA WestfaliaSurge $\mathrm{GmbH}$ ) and stored electronically (DairyPlan C21, GEA WestfaliaSurge $\mathrm{GmbH}$ ). Daily milk yield was standardized to ECM (4.0\% fat and $3.4 \%$ protein content) by $\operatorname{ECM}(\mathrm{kg} / \mathrm{d})=[(0.38 \times$ fat $\%+0.21 \times$ protein $\%+$
1.05)/3.28] × milk yield $(\mathrm{kg} / \mathrm{d})$ (Fischer et al., 2002). Analysis of milk components (protein, fat, and SCC) was done on samples collected at the afternoon milking. Because milking intervals were similar between

Table 2. Ingredients and chemical composition of the partial mixed ration $^{1}$

\begin{tabular}{lcc}
\hline Item & LD & DPD \\
\hline Ingredient, \% & & \\
Corn silage & 60 & 43 \\
Grass silage & 23 & 25 \\
Hay & 4 & 32 \\
Feed pellets ${ }^{2}$ & 12 & - \\
Mineral mix $^{3}$ & 1 & - \\
Chemical composition, \% unless noted & 45.2 & 52.0 \\
DM & 12.2 & 12.9 \\
CP & 18.6 & 19.2 \\
Crude fiber & 26.4 & 9.92 \\
NFC & 3.16 & 3.16 \\
Ether extract & 1.55 & 1.36 \\
NE $_{\mathrm{L}}{ }^{4}$ Mcal/kg & & \\
\hline
\end{tabular}

${ }^{1}$ Lactation diet (LD) was fed to all cows; dry period diet (DPD) was fed only to cows having a 56-d dry period (control and once daily milking cows, not continuous milking cows).

${ }^{2}$ Composition: corn gluten, $18.4 \%$; turnips molasses chips, $13.8 \%$; wheat, $10.0 \%$; triticale, $10.0 \%$; rape cake, $10.0 \%$; maize, $8.8 \%$; malt germ, 6.0\%; grain distillation residual (ProtiGrain), 5\%; rape extraction grist, $5 \%$; rumen protected rape extraction grist, $5 \%$; palm corn cake, $3.3 \%$; soy extraction grist, $2.8 \%$; sodium bicarbonate, $1.0 \%$; calcium bicarbonate, $0.99 \%$; plant oil (palm coconut), $0.40 \%$ (Raiffeisen Kraftfutterwerke Süd GmbH, Würzburg, Germany).

${ }^{3}$ Ingredients: Ca, 14\%; Na, 10.0\%; P, 5.0\%; Mg, 5.0\% (Josera, Kleinheubach, Germany).

${ }^{4}$ Estimates determined from tabulated values of feeds (GfE, 2007) and according to the following formula: $\mathrm{NE}_{\mathrm{L}}(\mathrm{Mcal} / \mathrm{kg})=0.6 \times[1+0.004$ $\times(\mathrm{q}-57)] \times \mathrm{ME}(\mathrm{Mcal} / \mathrm{kg})$, where $\mathrm{q}=\mathrm{ME} / \mathrm{GE}$. Here, $\mathrm{q}=88.9$. 
morning and afternoon milkings, measurements in afternoon samples were reliable estimations of the contents in daily milk in agreement with Lee and Wardrop (1984). Samples $(\sim 1 \mathrm{~L})$ were collected during milking. The amount of milk separated into the sample pot was controlled by milk flow-rate and total amount of milk to get a proportional subsample (Metatron P21, GEA WestfaliaSurge $\mathrm{GmbH}$ ). A 50-mL aliquot was taken and stored at $4^{\circ} \mathrm{C}$ for a maximum of $10 \mathrm{~d}$ with a preservative (acidiol) until analyses. Milk composition of cows in CM was analyzed twice weekly until calving. After parturition, milk composition of all cows was determined daily for the first week, twice weekly to 56 DIM, once weekly from 57 to 100 DIM, and then once every 2 wk to 305 DIM.

Blood samples from all cows were collected by jugular venipuncture at $\mathrm{wk}-4,-2$, and -1 before expected calving, within $24 \mathrm{~h}$ postpartum (wk 0), and at wk 1, 2, 4, 6, 8, 12, 16, 24, 36, and 44. Samples were collected into 7-mL vacuum tubes (Vacuette, Greiner Bio-One, Kremsmünster, Austria) at 0700 (after milking); within $1 \mathrm{~h}$, blood serum was separated by centrifugation $\left(2,000 \times g ; 4^{\circ} \mathrm{C} ; 15 \mathrm{~min}\right)$. Three aliquots $(1.5 \mathrm{~mL})$ of serum were stored at $-20^{\circ} \mathrm{C}$.

\section{Backfat Thickness and BCS}

Subcutaneous adipose tissue (backfat thickness) was assessed with ultrasonography (Sonovet 2000, Universal Ultrasound, Bedford Hills, NY) near the pelvic region (Schröder and Staufenbiel, 2006). The BCS was determined by the same person once every 2 wk from wk -8 to the end of the study (wk 44) using a scale from 1 to $5(1=$ emaciated, $5=$ obese $)$ in increments of 0.25 (Edmonson et al., 1989).

\section{Analyses}

Milk protein and fat were analyzed by infrared spectrophotometry (MilkoScan FT6000, Foss, Hillerød, Denmark), and SCC was determined with a fluorescence optical counting system (Fossomatic FC, Foss) in the laboratories of Milchprüfring Bayern e.V. (Wolnzach, Germany). Serum concentrations of glucose, NEFA, BHBA, and total bilirubin (TB) were determined with an automated clinical chemistry analyzer (ABX Pentra 400, Horiba, Montpellier, France); precision of 20 measurements of 1 sample was expressed as the respective relative coefficient of variation. Glucose concentrations were analyzed by using hexokinase method (Hoffmann La-Roche, Basel, Switzerland; $\mathrm{CV}=2.3 \%$ ), NEFA concentrations were measured using colorimetric enzymatic reactions $(\mathrm{CV}=6.2 \%)$, BHBA was determined using a spectrophotometric enzymatic analysis (Sigma-
Aldrich Diagnostics, Munich, Germany; CV $=7.1 \%$ ), and TB was determined with the Jandrassik/Grof reaction (Jandrassik and Grof, 1938). Calibration and quality controls were done daily. The threshold values are based on Macrae et al. (2006).

\section{Statistics}

End points measured repeatedly (daily milk yield, milk composition) were pooled to weekly means before statistical analysis. For BCS and backfat, an average value for every 4 wk from wk -8 to wk 40 was used.

For any metabolic key parameters in blood, as for milk yield, percentage milk protein, milk fat content, and milk protein and fat yield, treatment effects, and differences among groups were determined using REML in the MIXED procedure in SAS (SAS Institute, 2002). The model contained fixed effects of treatment and week and random effects of cow within treatment. For the repeated measurements, the model also contained weeks relative to calving and the interaction between treatment and weeks relative to calving. The effects of time, group, and time $\times$ group interactions were tested.

For each variable analyzed, 3 covariance structures were evaluated: compound symmetry, autoregressive order 1 , and unstructured. The covariance structure of repeated measurements that resulted in the Akaike's information criterion or Schwarz's Bayesian criterion closest to zero was used (Littell et al., 1998). Differences between treatments were determined using the PDIFF option.

Incidence of health disorders and the proportion of blood samples from wk 1 to 4 with low glucose, high NEFA, and high BHBA were tested for differences with PROC ANOVA using Dunnett's one-tailed $t$-test to locate differences. Results are reported as least squares means \pm standard error of means. Means were considered to differ significantly in case of $P<0.05$.

\section{RESULTS}

\section{Milk Yield}

Total lactational ECM yield (305 d) was highest for $\mathrm{C}$ cows $(11,310 \pm 601 \mathrm{~kg}$ of ECM). Compared with $\mathrm{C}$ cows, total ECM was 15.7 and $16.5 \%$ lower for ODM cows $(9,531 \pm 477 \mathrm{~kg}$ of ECM $)$ and CM cows $(9,447 \pm$ $310 \mathrm{~kg}$ of ECM), respectively (Figure 1A; Table 3).

Total milk yield of CM cows from $\mathrm{d}-56$ to parturition was $1,186 \pm 82 \mathrm{~kg}$ of ECM. Daily ECM yield declined by $57.3 \%$ from wk -8 to wk -1 relative to calving. During the last week before calving, average daily milk yield of CM cows was $14.4 \pm 2.1 \mathrm{~kg}$ of ECM. 

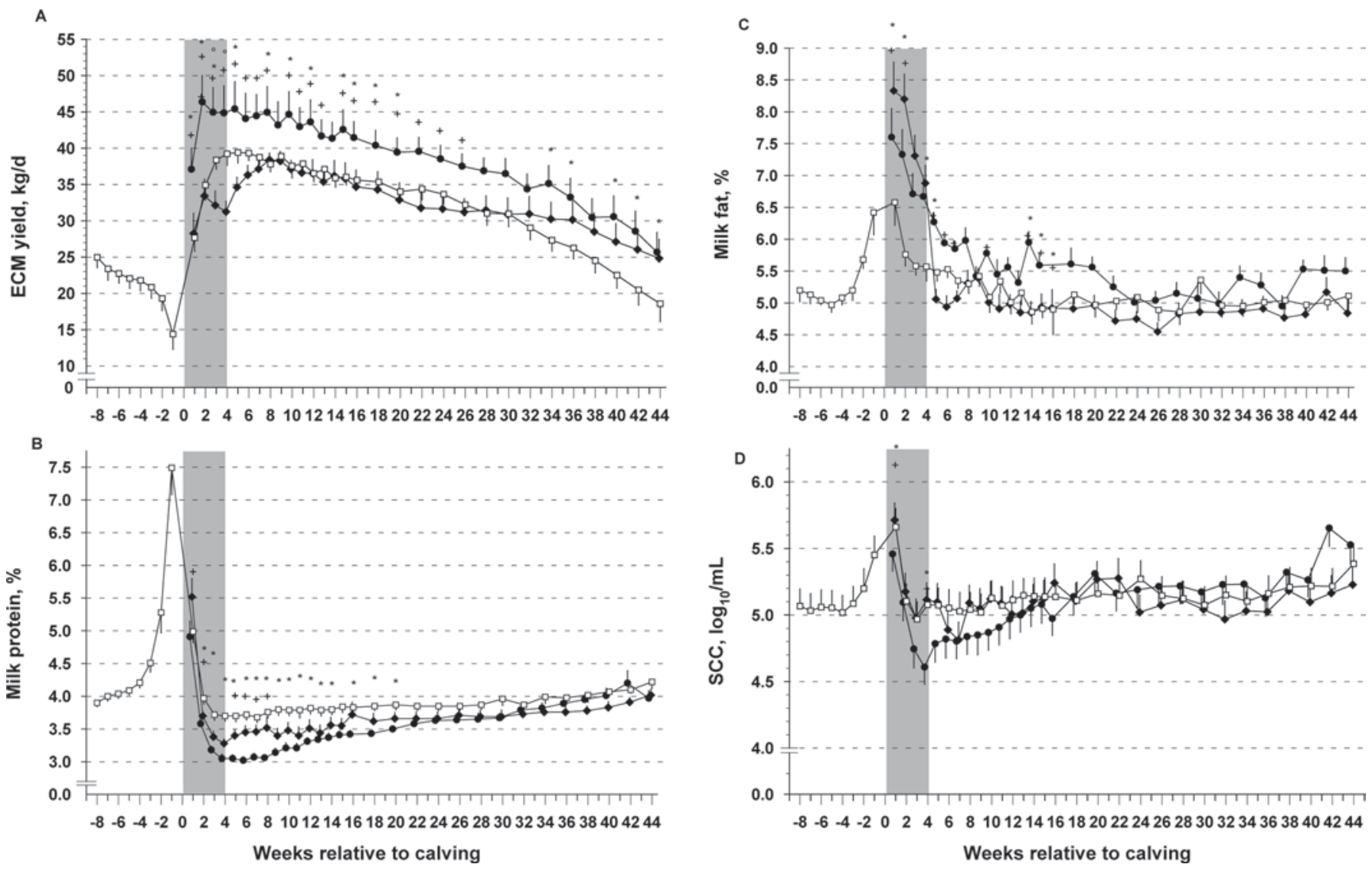

Figure 1. A) Energy-corrected daily milk yield (kg/d), B) milk protein concentration (\%), C) milk fat concentration (\%), and D) SCC pattern $\left(\log _{10} / \mathrm{mL}\right)$ from wk -8 before parturition up to wk 44 of lactation for Brown Swiss dairy cows assigned to 1 of 3 management strategies: 56-d dry period (DP) and twice daily milking after parturition (control, C: $\bullet$ ), 56-d DP and once daily milking (ODM) for the first $28 \mathrm{~d}$ of lactation $(\checkmark)$, and 0 -d DP with continuous milking (CM) twice daily throughout lactation $(\square)$. Asterisks indicate differences between $\mathrm{C}$ and $\mathrm{CM}$; plus signs indicate differences between $\mathrm{C}$ and ODM $(P<0.05)$; circles indicate differences between ODM and CM. Values are LSM \pm SEM. The gray box indicates time of different milking regimens in early lactation from 1 to 28 DIM.

The average dry-off milk yield was $17.7 \pm 2.0 \mathrm{~kg} / \mathrm{d}$ for $\mathrm{C}$ cows and $17.4 \pm 1.8 \mathrm{~kg} / \mathrm{d}$ for ODM cows.

Within the first 28 DIM, average daily milk yield was highest for $\mathrm{C}$ cows $(43.3 \pm 1.8 \mathrm{~kg}$ of $\mathrm{ECM} / \mathrm{d})$, which was $38 \%$ more than for ODM cows $(31.3 \pm 1.1 \mathrm{~kg}$ of $\mathrm{ECM} / \mathrm{d} ; P<0.001)$ and $24 \%$ more than for $\mathrm{CM}$ cows $(35.0 \pm 1.1 \mathrm{~kg}$ of ECM $/ \mathrm{d} ; P=0.005)$. During this time, ECM yield did not differ between ODM and CM cows. Milk yield for ODM cows increased from the start of twice daily milking at wk $5(P<0.001)$, but remained approximately $8.1 \mathrm{~kg} / \mathrm{d}$ of ECM (18\%) lower than for $\mathrm{C}$ cows $(P=0.01)$ until wk 8 . From wk 5 to wk 20, ODM cows produced about $7.3 \mathrm{~kg} / \mathrm{d}(15.7 \%)$ and $\mathrm{CM}$ cows about $6.5 \mathrm{~kg} / \mathrm{d}(13.7 \%)$ less ECM than C cows. Yield of ECM peaked at wk 2 for $\mathrm{C}$ cows $(46.4 \pm 3.6$ $\mathrm{kg}$ of $\mathrm{ECM} / \mathrm{d})$, at wk 5 for $\mathrm{CM}$ cows $(39.4 \pm 1.5 \mathrm{~kg}$ of $\mathrm{ECM} / \mathrm{d})$, and at wk 8 for ODM cows $(38.4 \pm 1.2 \mathrm{~kg}$ of $\mathrm{ECM} / \mathrm{d})$.

\section{Milk Composition}

Milk protein and milk fat content increased for CM cows from wk -8 to $\mathrm{wk}-1$ relative to calving (3.90 \pm $0.06 \%$ to $7.49 \pm 0.41 \%, P<0.001$, and $5.20 \pm 0.18 \%$ to $6.42 \pm 0.35 \%, P=0.001$, for milk protein and milk fat content, respectively; Figure $1 \mathrm{~B}$ and $\mathrm{C})$. From wk -8 to wk -1 , daily fat yield decreased $(1.02 \pm 0.40 \mathrm{~kg} / \mathrm{d}$ to $0.64 \pm 0.31 \mathrm{~kg} / \mathrm{d} ; P<0.01)$ in milk of $\mathrm{CM}$ cows, whereas daily protein yield remained constant $(0.75 \pm$ $0.26 \mathrm{~kg} / \mathrm{d}$ to $0.71 \pm 0.32 \mathrm{~kg} / \mathrm{d} ; P=0.19)$.

Milk protein concentration decreased steeply for $\mathrm{C}$ cows from wk $1(4.91 \pm 0.8 \%)$ to wk $4(3.05 \pm 0.23 \%$; $P<0.001)$. For the first 4 wk postpartum, milk protein concentration was higher in both ODM cows $(3.97 \pm$ $1.07 \% ; P=0.041)$ and $\mathrm{CM}$ cows $(4.06 \pm 0.63 \% ; P=$ $0.009)$ compared with $\mathrm{C}$ cows $(3.65 \pm 0.12 \%)$. However, reduced milk volume for ODM cows resulted in lower 
Table 3. Energy-corrected milk yield (LSM \pm SEM) during the last $56 \mathrm{~d}$ before calving for CM cows and for the first, second, and third 100-d interval of a 305-d lactation period compared among experimental groups

\begin{tabular}{|c|c|c|c|c|c|c|}
\hline \multirow[b]{2}{*}{ Item } & \multicolumn{3}{|c|}{ Treatment group ${ }^{1}$} & \multicolumn{3}{|c|}{$P$-value ${ }^{2}$} \\
\hline & $\mathrm{C}$ & ODM & $\mathrm{CM}$ & $\mathrm{C}$ vs. ODM & $\mathrm{C}$ vs. $\mathrm{CM}$ & ODM vs. CM \\
\hline Average $\mathrm{kg} / \mathrm{d}$ & & & $21.2 \pm 1.5$ & & & \\
\hline Total & & & $1,186 \pm 82$ & & & \\
\hline \multicolumn{7}{|l|}{1 to 100 DIM } \\
\hline Average $\mathrm{kg} / \mathrm{d}$ & $44.9 \pm 2.8$ & $37.6 \pm 1.2$ & $37.8 \pm 0.9$ & 0.025 & 0.021 & 0.99 \\
\hline Average kg/d & $39.2 \pm 1.9$ & $32.5 \pm 2.1$ & $33.6 \pm 1.3$ & 0.017 & 0.005 & 0.6256 \\
\hline Total & $3,987 \pm 186$ & $3,323 \pm 212$ & $3,434 \pm 131$ & 0.013 & 0.040 & 0.67 \\
\hline \multicolumn{7}{|l|}{201 to 305 DIM } \\
\hline Average kg/d & $31.8 \pm 2.3$ & $28.5 \pm 2.3$ & $25.0 \pm 1.6$ & 0.043 & 0.003 & 0.31 \\
\hline Total & $2,975 \pm 230$ & $2,694 \pm 229$ & $2,306 \pm 154$ & 0.29 & 0.012 & 0.14 \\
\hline \multicolumn{7}{|l|}{ 305-d lactation yield } \\
\hline Average kg/d & $38.2 \pm 0.56$ & $32.4 \pm 0.41$ & $30.5 \pm 0.45$ & 0.04 & 0.005 & 0.12 \\
\hline
\end{tabular}

${ }^{1} \mathrm{C}=$ control group: cows were dried off $56 \mathrm{~d}$ before calving and milked twice daily throughout next lactation $(305 \mathrm{~d} ; \mathrm{n}=12)$; ODM = once daily milking group: cows were dried off $56 \mathrm{~d}$ before calving and milked once daily for the first $4 \mathrm{wk}$ of lactation and twice daily for the remaining lactation $(\mathrm{n}=12) ; \mathrm{CM}=$ continuous milking group: cows were milked twice daily until calving and also during the subsequent lactation $(\mathrm{n}=12)$.

${ }^{2}$ Means are different among groups $(P<0.05)$.

daily protein yield for these cows $(0.83 \pm 0.22 \mathrm{~kg} / \mathrm{d})$ compared with $\mathrm{C}$ cows $(1.13 \pm 0.3 \mathrm{~kg} / \mathrm{d} ; P=0.007)$ and $\mathrm{CM}$ cows $(1.15 \pm 0.14 \mathrm{~kg} / \mathrm{d} ; P=0.007)$. The CM cows had a higher weekly milk protein concentration for the first 20 wk of lactation compared with $\mathrm{C}$ cows $(3.85 \pm 0.07 \%$ vs. $3.34 \pm 0.07 \% ; P=0.005)$.

During the first 4 wk of lactation, milk fat concentration was highest for ODM cows $(7.67 \pm 0.20 \%)$ compared with $\mathrm{C}$ cows $(7.07 \pm 0.20 \% ; P<0.02)$ and $\mathrm{CM}$ cows (5.84 $\pm 0.13 \% ; P<0.001$; Figure $1 \mathrm{C})$. Daily fat yield was $36 \%$ higher for $\mathrm{C}$ cows $(2.23 \pm 0.73 \mathrm{~kg} / \mathrm{d})$ compared with ODM cows $(1.64 \pm 0.47 \mathrm{~kg} / \mathrm{d} ; P<$ $0.001)$ and $33 \%$ higher compared with CM cows (1.68 $\pm 0.32 \mathrm{~kg} / \mathrm{d} ; P<0.001 ;$ Table 4$)$.
Somatic cell count differed only at wk 1 between cows in group $\mathrm{C}\left(5.34 \pm 0.4 \log _{10} \mathrm{SCC}\right)$ and group ODM (5.47 $\left.\pm 0.4 \log _{10} \mathrm{SCC} ; P=0.042\right)$. No differences were found for SCC among treatment groups at any other time points (Figure 1D).

\section{Health and Occurrence of Diseases}

Five C cows, 2 ODM cows, and 3 CM cows suffered from clinical mastitis; 2 of the latter had infections of the udder during the last week before calving. A retained placenta was observed in $2 \mathrm{C}$ cows, 5 ODM cows, and $1 \mathrm{CM}$ cow. One ODM cow suffered from clinical hypocalcemia, and primary ketosis was diagnosed in 3

Table 4. Milk protein yield, milk fat yield, milk protein concentration, and milk fat concentration (LSM \pm SEM) compared among treatment groups for 305-d lactation ${ }^{1}$

\begin{tabular}{|c|c|c|c|c|c|c|c|c|}
\hline \multirow[b]{2}{*}{ Item } & \multicolumn{4}{|c|}{ Treatment group ${ }^{2}$} & \multicolumn{4}{|c|}{$P$-value ${ }^{3}$} \\
\hline & $\mathrm{C}$ & ODM & CM (1 to 305 DIM) & $\begin{array}{c}\mathrm{CM}^{+}(-56 \text { to } \\
305 \mathrm{DIM})\end{array}$ & $\begin{array}{c}\text { ODM } \\
\text { vs. CM }\end{array}$ & $\begin{array}{l}\text { C vs. } \\
\text { ODM }\end{array}$ & $\begin{array}{l}\text { C vs. } \\
\text { CM }\end{array}$ & $\begin{array}{l}\mathrm{C} \text { vs. } \\
\mathrm{CM}^{+}\end{array}$ \\
\hline Protein, \% & $3.52 \pm 0.3(100)$ & $3.79 \pm 0.41(107)$ & $3.91 \pm 0.28(110)$ & $4.04 \pm 0.27(115)$ & 0.07 & 0.06 & $<0.001$ & $<0.001$ \\
\hline Fat, $\%$ & $5.50 \pm 0.2(100)$ & $5.15 \pm 0.1(94)$ & $4.70 \pm 0.1(85)$ & $5.33 \pm 0.30(97)^{\prime}$ & 0.03 & 0.05 & $<0.001$ & 0.13 \\
\hline Protein yield, kg & $342 \pm 15(100)$ & $311 \pm 16(91)$ & $325 \pm 12(95)$ & $367 \pm 14(107)$ & 0.52 & 0.14 & 0.39 & 0.26 \\
\hline Fat yield, kg & $541 \pm 37(100)$ & $437 \pm 23(81)$ & $417 \pm 16(77)$ & $484 \pm 25(89)$ & 0.924 & 0.006 & 0.005 & 0.13 \\
\hline Daily fat yield, kg & $1.87 \pm 0.08$ & $1.42 \pm 0.08$ & $1.38 \pm 0.08$ & $1.26 \pm 0.08$ & 0.78 & 0.002 & 0.004 & $<0.001$ \\
\hline Daily protein yield, $\mathrm{kg}$ & $1.08 \pm 0.05$ & $0.99 \pm 0.05$ & $1.10 \pm 0.04$ & $1.03 \pm 0.05$ & 0.09 & 0.81 & 0.15 & 0.07 \\
\hline $\mathrm{SCC}, \log _{10}$ cells $/ \mathrm{mL}$ & $5.06 \pm 0.08$ & $5.10 \pm 0.08$ & $5.13 \pm 0.08$ & $5.15 \pm 0.08$ & 0.79 & 0.77 & 0.57 & 0.59 \\
\hline
\end{tabular}

${ }^{1}$ Data in relation to control (set 100) are given in parentheses.

${ }^{2} \mathrm{C}=$ control group: cows were dried off $56 \mathrm{~d}$ before calving and milked twice daily throughout next lactation (305 d; $\left.\mathrm{n}=12\right) ; \mathrm{ODM}=$ once daily milking group: cows were dried off $56 \mathrm{~d}$ before calving and milked once daily for the first 4 wk of lactation and twice daily for the remaining lactation $(\mathrm{n}=12) ; \mathrm{CM}=$ continuous milking group: cows were milked twice daily until calving and also during the subsequent lactation $(\mathrm{n}=$ 12). $\mathrm{CM}+=\mathrm{CM}$ group, but for calculation of LSM of total lactation values, the extra days of milking (from wk -8 up to day of calving) were included. Values in parentheses represent the timeframe relative to calving from which data were obtained.

${ }^{3}$ Means are different among groups $(P<0.05)$. 
Table 5. Occurrence of diseases (number of events) in the treatment groups during study ${ }^{1}$

\begin{tabular}{|c|c|c|c|c|}
\hline \multirow[b]{2}{*}{ Diagnosis } & \multicolumn{3}{|c|}{ Treatment group ${ }^{2}$} & \multirow[b]{2}{*}{$P$-value ${ }^{3}$} \\
\hline & $\mathrm{C}$ & ODM & $\mathrm{CM}$ & \\
\hline Mastitis & $5(3,15,109,248,263)$ & $2(61,118)$ & $3(-7,-5,60)$ & 0.47 \\
\hline Retained placenta & $2(1)$ & $5(1)$ & $1(1)$ & 0.61 \\
\hline Hypocalcemia & 0 & $1(1)$ & 0 & 0.56 \\
\hline Ketosis & $3(13,31,32)$ & 0 & 0 & 0.18 \\
\hline Lameness & $2(33,53)$ & $2(86,88)$ & 0 & 0.21 \\
\hline
\end{tabular}

$\mathrm{C}$ cows. Two each of $\mathrm{C}$ and ODM cows became lame (Table 5).

\section{Blood Analysis}

Before Parturition. Before parturition there were no differences in serum concentration of glucose, NEFA, BHBA, and TB among treatment groups except during the last week before calving, when serum NEFA concentrations were higher for ODM cows compared with $\mathrm{CM}$ cows $(467 \pm 88 \mu \mathrm{mol} / \mathrm{L}$ vs. $216 \pm 79 \mu \mathrm{mol} / \mathrm{L}$; $P=0.025)$.

At Parturition. Serum glucose concentration did not differ between groups at parturition. The $\mathrm{C}$ cows and ODM cows had higher blood NEFA concentrations compared with CM cows. The $\mathrm{C}$ cows had similar blood BHBA concentrations compared with ODM cows but higher blood BHBA concentrations compared with CM cows. Total bilirubin was highest for ODM cows compared with $\mathrm{C}$ and $\mathrm{CM}$ cows (Figure 2A, B, C, and D; Table 6).

Wk 1 to 4 Postpartum. Blood glucose concentration was lowest for $\mathrm{C}$ cows for the first 2 wk of lactation $(2.62 \pm 0.82 \mathrm{mmol} / \mathrm{L}$ at wk 1 and $2.72 \pm 0.81 \mathrm{mmol} / \mathrm{L}$ at wk 2) compared with $\mathrm{CM}$ cows $(3.29 \pm 0.27 \mathrm{mmol} / \mathrm{L}$ at wk $1, P=0.006$, and $3.40 \pm 0.30 \mathrm{mmol} / \mathrm{L}$ at wk $2, P$ $<0.001)$ and ODM cows $(3.16 \pm 0.5 \mathrm{mmol} / \mathrm{L}$ at wk 1 , $P=0.032$, and $3.29 \pm 0.32 \mathrm{mmol} / \mathrm{L}$ at wk $2, P<0.005$; Figure 2D; Table 6). On average during the first $4 \mathrm{wk}$ of lactation, blood glucose concentration was lowest for $\mathrm{C}$ cows compared with ODM and CM cows. During the first $4 \mathrm{wk}$ of lactation, blood serum NEFA concentrations were $44 \%$ lower for ODM cows and $66 \%$ lower for CM cows compared with C cows. Like NEFA, blood BHBA concentrations for $\mathrm{C}$ cows were approximately twice as high as for ODM cows and approximately thrice as high as for CM cows. Simultaneously, CM cows had about half the TB blood concentration of $\mathrm{C}$ cows. The latter was comparable to the TB concentration measured in blood serum of ODM cows (Figure 2A, B, and C; Table 6).

Furthermore, considering blood samples collected in wk 1,2, and 4 of lactation, a proportion of samples was assessed in which established alarm levels of metabolic key parameters in herd medicine were exceeded. A higher percentage of $\mathrm{C}$ cows exhibited hypoglycemia compared with ODM and CM cows (47, 20, and 14\%, respectively; $P<0.05$ ). Moreover, the proportion of $\mathrm{C}$ cows with excessive lipomobilization and ketonemia was higher compared with those of the other treatment groups (Table 7 ).

From wk 5 to 8, glucose concentration did not differ between groups. Concentrations of NEFA and TB were higher for $\mathrm{C}$ cows than for ODM cows and CM cows. Blood serum BHBA concentrations were higher in $\mathrm{C}$ cows than in $\mathrm{CM}$ cows (Figure 2A, B, C, and D; Table 6). No differences between treatment groups were obvious for any of the analyzed blood parameters from wk 12 to 44 .

\section{Backfat Thickness and BCS}

Backfat thickness was not different among treatments at any time point (Figure 3A). It declined from mo -2 before to mo 2 after calving by 24, 19, and $25 \%$ for C, ODM, and CM cows, respectively (i.e., a decrease of on average $5.8 \pm 0.7 \mathrm{~mm} ; P<0.001)$. After calving, backfat thickness declined from mo 1 to 4 by approximately $40 \%$ for $\mathrm{C}$ cows $(21.4 \pm 2.3$ to $13.1 \pm 1.9 \mathrm{~mm}$; $P<0.001)$ and by $17 \%$ for ODM cows $(23.7 \pm 3.3$ to $19.6 \pm 3.9 \mathrm{~mm} ; P=0.06)$. The $\mathrm{C}$ cows exhibited the most pronounced decrease between calving and mo 3 of lactation, followed by an increase of backfat thickness until mo 10 of lactation by $63 \%(15.6 \pm 2.3$ to $25.4 \pm$ $3.3 \mathrm{~mm} ; P<0.001)$. Backfat thickness increased from mo 4 of lactation to mo 10 in ODM cows by approxi- 
A

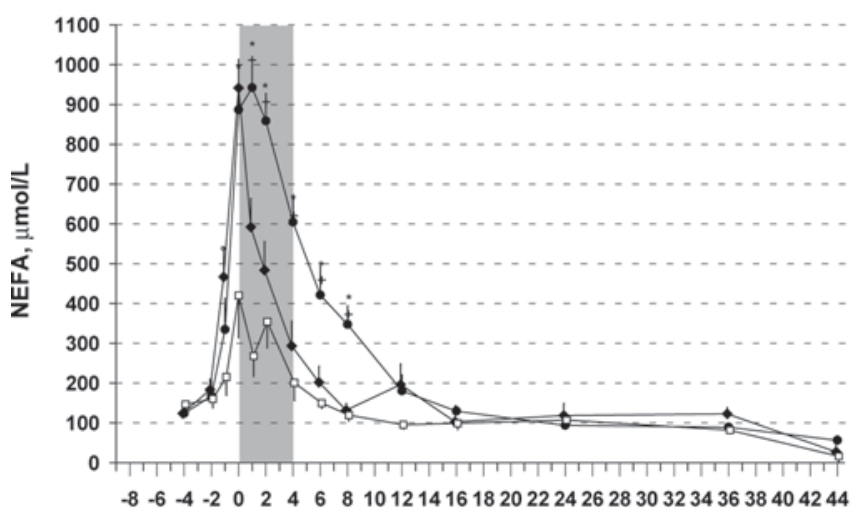

B

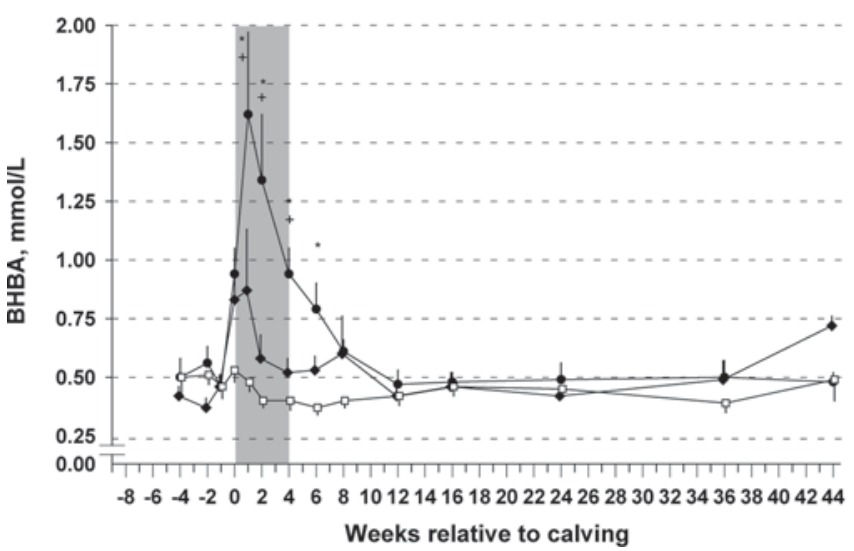

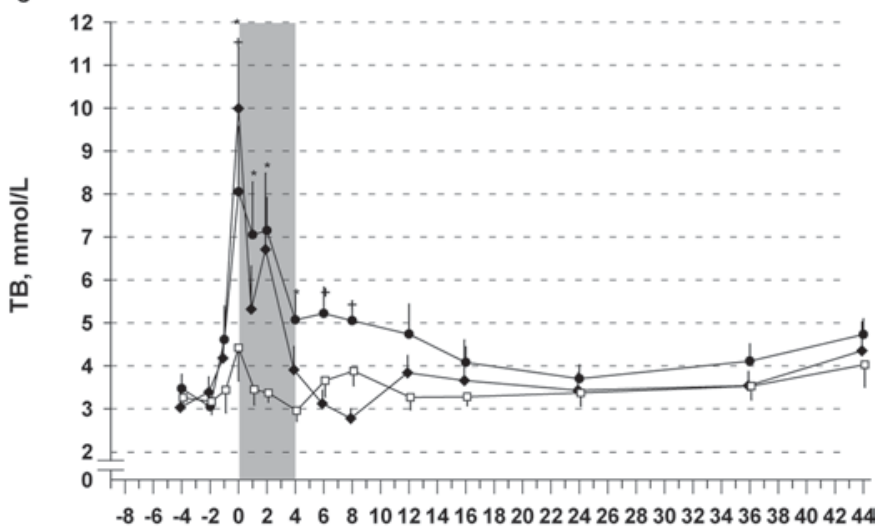

D

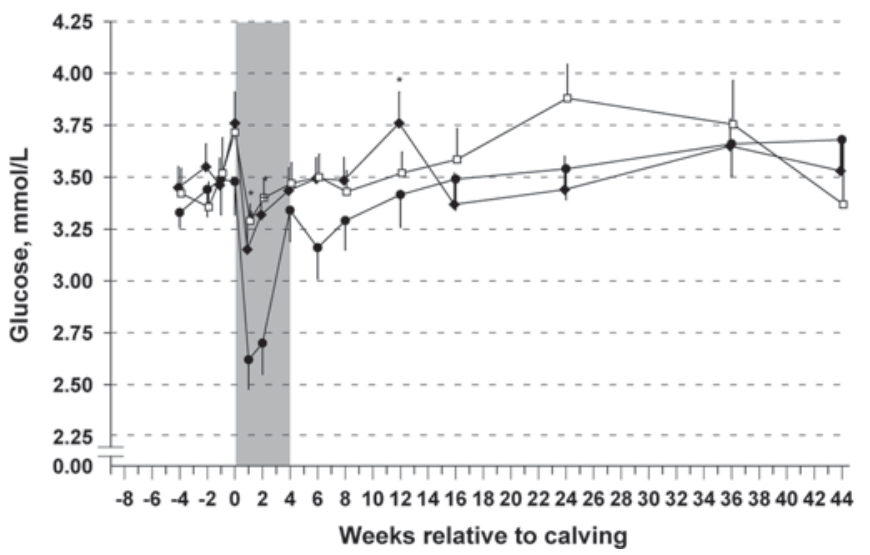

Figure 2. A) NEFA, B), BHBA, C) total bilirubin (TB), and D) glucose concentrations in blood of cows assigned to 1 of 3 different management strategies: 56-d dry period (DP) and twice daily milking after parturition (control, C; $\bullet$ ), 56-d DP and once daily milking (ODM) for the first $28 \mathrm{~d}$ of lactation $(\bullet)$, and 0-d DP with continuous milking (CM) twice daily throughout lactation ( $\square$ ). Asterisks indicate that blood serum concentrations differed between $\mathrm{C}$ and $\mathrm{CM}$; plus signs indicate that blood serum concentrations differed between C and ODM; circles indicate that blood serum concentrations differed between ODM and CM $(P<0.05)$. Values are LSM \pm SEM. The gray box indicates time of different milking regimens.

mately $28 \%(22.0 \pm 3.8$ to $29.4 \pm 3.2 \mathrm{~mm} ; P<0.001)$. For CM cows, increase of backfat thickness started 2 mo earlier compared with ODM cows already at wk 6; backfat thickness increased by $74 \%(15.7 \pm 2.1$ to 27.3 $\pm 2.7 \mathrm{~mm} ; P<0.001)$.

Before calving, BCS did not differ between $\mathrm{C}$ cows at mo $-2(3.7 \pm 0.3)$ and $\mathrm{mo}-1(4.0 \pm 0.5)$ relative to calving compared with $\mathrm{CM}$ cows $(3.5 \pm 0.4, P=0.84$, and $3.6 \pm 0.5, P=0.23$ for mo -2 and -1 , respectively) and ODM cows $(3.7 \pm 0.51, P=0.51$, and 3.8 $\pm 0.4, P=0.11$ for $\mathrm{mo}-2$ and -1 , respectively; Figure $3 \mathrm{~B})$. The BCS was lower in the first month of lactation in $\mathrm{C}$ cows compared with ODM cows $(2.9 \pm 0.5$ vs. $3.39 \pm 0.5 ; P=0.022)$ and $\mathrm{CM}$ cows $(3.3 \pm 0.5 ; P=$ 0.03). Decrease of BCS between the first and the third month of lactation was most pronounced in $\mathrm{C}$ cows $(0.31 \pm 0.09 ; P<0.001)$. A smaller reduction in BCS was found for ODM cows $(0.20 \pm 0.09 ; P=0.92)$ and $\mathrm{CM}$ cows $(0.16 \pm 0.09 ; P=0.08)$. The BCS of CM cows steadily increased between the first $(3.1 \pm 0.2)$ and tenth $(3.6 \pm 0.1)$ month of lactation $(P=0.004)$. For C cows, BCS increased by $24 \%$ between the third (2.9 $\pm 0.1)$ and the tenth $(3.6 \pm 0.2)$ month of lactation $(P$ $<0.001)$, whereas BCS for ODM cows increased in this timeframe by $15 \%(3.3 \pm 0.5$ to $3.8 \pm 0.6 ; P=0.004)$.

\section{DISCUSSION}

The objective was to characterize the effects of 2 different approaches adopted to reduce metabolic stress throughout the transition period in high-yielding dairy cows. Brown Swiss cows for the treatment groups were recruited from the Technische Universitaet Muenchen herd in which the breeding strategy for a decade was designed to maximize milk protein. Thereby, the protein percentage in the University herd's tank milk (mean during the last $15 \mathrm{yr}: 3.69 \%$ ) is somewhat higher than that of the German Holstein population 
Table 6. Least squares means \pm SEM of serum metabolites of dairy cows managed with different milking regimens during dry period and early lactation

\begin{tabular}{|c|c|c|c|c|c|c|}
\hline \multirow[b]{2}{*}{ Item } & \multicolumn{3}{|c|}{ Treatment group ${ }^{1}$} & \multicolumn{3}{|c|}{$P$-value ${ }^{2}$} \\
\hline & $\mathrm{C}$ & ODM & $\mathrm{CM}$ & C vs. ODM & $\mathrm{C}$ vs. $\mathrm{CM}$ & ODM vs. CM \\
\hline Before parturition & $3.50 \pm 0.11$ & $3.51 \pm 0.12$ & $3.44 \pm 0.11$ & 0.96 & 0.73 & 0.70 \\
\hline At parturition & $3.56 \pm 0.25$ & $3.76 \pm 0.15$ & $3.74 \pm 0.15$ & 0.22 & 0.51 & 0.58 \\
\hline Wk 1 to 4 & $2.95 \pm 0.1$ & $3.29 \pm 0.1$ & $3.39 \pm 0.05$ & 0.04 & 0.01 & 0.63 \\
\hline Wk 5 to 8 & $3.23 \pm 0.11$ & $3.49 \pm 0.07$ & $3.46 \pm 0.07$ & 0.089 & 0.1 & 0.92 \\
\hline Before parturition & $177 \pm 50$ & $257 \pm 51$ & $170 \pm 49$ & 0.27 & 0.92 & 0.22 \\
\hline At parturition & $831 \pm 71$ & $868 \pm 71$ & $414 \pm 75$ & 0.48 & $<0.001$ & $<0.001$ \\
\hline Wk 1 to 4 & $778 \pm 45$ & $435 \pm 46$ & $266 \pm 45$ & $<0.001$ & $<0.001$ & 0.008 \\
\hline Wk 5 to 8 & $389 \pm 52$ & $172 \pm 51$ & $137 \pm 52$ & 0.004 & $<0.001$ & 0.62 \\
\hline Wk 12 to 44 & $110 \pm 133$ & $129 \pm 38$ & $91 \pm 37$ & 0.70 & 0.70 & 0.47 \\
\hline \multicolumn{7}{|l|}{ BHBA, mmol/L } \\
\hline Before parturition & $0.48 \pm 0.07$ & $0.40 \pm 0.07$ & $0.48 \pm 0.07$ & 0.80 & 0.52 & 0.86 \\
\hline Before parturition & $3.62 \pm 0.46$ & $3.56 \pm 0.46$ & $3.28 \pm 0.45$ & 0.92 & 0.59 & 0.67 \\
\hline At parturition & $7.51 \pm 0.58$ & $9.59 \pm 0.60$ & $4.24 \pm 0.60$ & 0.026 & $<0.001$ & $<0.001$ \\
\hline Wk 1 to 4 & $6.38 \pm 0.42$ & $5.27 \pm 0.42$ & $3.23 \pm 0.41$ & 0.07 & $<0.001$ & 0.007 \\
\hline Wk 5 to 8 & $5.23 \pm 0.47$ & $3.06 \pm 0.47$ & $3.78 \pm 0.47$ & 0.002 & 0.033 & 0.28 \\
\hline Wk 12 to 44 & $4.25 \pm 0.29$ & $3.68 \pm 0.33$ & $3.39 \pm 0.34$ & 0.2 & 0.06 & 0.54 \\
\hline
\end{tabular}

${ }^{1} \mathrm{C}=$ control group: cows were dried off $56 \mathrm{~d}$ before calving and milked twice daily throughout next lactation $(305 \mathrm{~d} ; \mathrm{n}=12) ; \mathrm{ODM}=$ once daily milking group: cows were dried off $56 \mathrm{~d}$ before calving and milked once daily for the first 4 wk of lactation and twice daily for the remaining lactation $(\mathrm{n}=12) ; \mathrm{CM}=$ continuous milking group: cows were milked twice daily until calving and also during the subsequent lactation $(\mathrm{n}=12)$.

${ }^{2}$ Means are different among groups $(P<0.05)$.

${ }^{3} \mathrm{~TB}=$ total bilirubin.

(roughly 3.38\%). Furthermore, the implementation of a transponder-based concentrate feeding system and the availability of a superior maize silage induced a significant increase in milk yield during the experimental period compared with former years.

Nine out of 45 cows left the herd because of severe health problems during the study period; this culling rate $(20 \%)$ was similar to that of previous investigations (Reist et al., 2003). Nevertheless, the remaining group size ( $\mathrm{n}=12$ cows/group) allowed the investigation of treatment effects for blood serum parameters and parameters of milk yield and composition with a statistical power of 0.8 based on previously obtained standard deviations and generally accepted differences of means. However, the present experimental design did not provide sufficient statistical power to evaluate possible differences among groups for health disorders. Statistical power analysis revealed that at least 38 cows for each group were needed for unbiased statistical comparisons of health disorders.

Because of the limited group size, the lower incidence of diseased $\mathrm{CM}$ cows compared with $\mathrm{C}$ cows did not

Table 7. Percentage of blood samples (36 samples/group) collected in wk 1, 2, and 4 of lactation exceeding established alarm levels of metabolic key parameters in herd medicine of all treatment groups

\begin{tabular}{|c|c|c|c|c|c|c|c|}
\hline Parameter & Threshold value $^{1}$ & \multicolumn{3}{|c|}{ Treatment group ${ }^{2}$} & \multicolumn{3}{|c|}{$P$-value ${ }^{3}$} \\
\hline Glucose & $\leq 3.0 \mathrm{mmol} / \mathrm{L}$ & 47.1 & 20.0 & 13.9 & $<0.001$ & $<0.001$ & 0.81 \\
\hline NEFA & $\geq 700 \mu \mathrm{mol} / \mathrm{L}$ & 41.2 & 17.1 & 8.3 & 0.012 & $<0.001$ & 0.9 \\
\hline
\end{tabular}

${ }^{1}$ Threshold values are based on our own experience and data of Macrae et al. (2006).

${ }^{2} \mathrm{C}=$ control group: cows were dried off $56 \mathrm{~d}$ before calving and milked twice daily throughout next lactation $(305 \mathrm{~d} ; \mathrm{n}=12) ; \mathrm{ODM}=$ once daily milking group: cows were dried off $56 \mathrm{~d}$ before calving and milked once daily for the first 4 wk of lactation and twice daily for the remaining lactation $(\mathrm{n}=12)$; $\mathrm{CM}=$ continuous milking group: cows were milked twice daily until calving and also during the subsequent lactation $(\mathrm{n}=12)$.

${ }^{3}$ Means are different among groups $(P<0.05)$. 


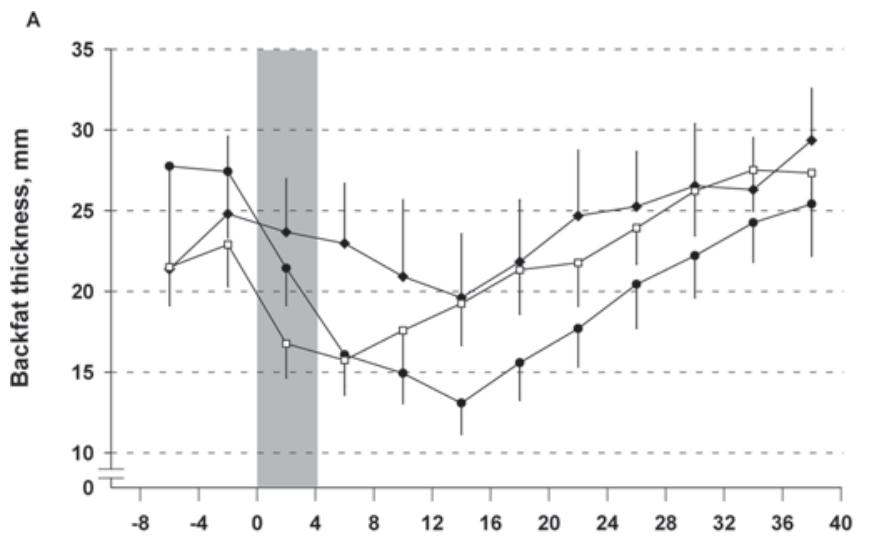

B

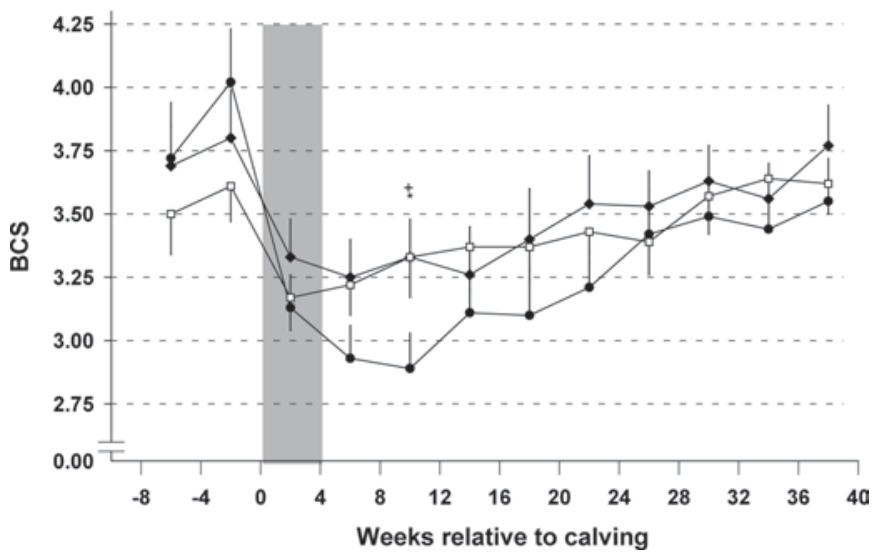

Figure 3. Changes of backfat thickness and BCS from month -2 before parturition to mo 10 of lactation for cows assigned to 1 of 3 different management strategies: 56-d dry period (DP) and twice daily milking after parturition (control, C; $)$, 56-d DP and once daily milking $(\mathrm{ODM})$ for the first $28 \mathrm{~d}$ of lactation $(\bullet)$, and $0-\mathrm{d}$ DP and continuous milking $(\mathrm{CM})$ twice daily throughout lactation $(\square)$. Asterisks indicate differences between $\mathrm{C}$ and $\mathrm{CM}$; plus signs indicate differences between $\mathrm{C}$ and ODM $(P<0.05)$.

allow the suggestion that this is a valid difference. Three C cows, but no CM cows, suffered from ketosis; however, with 12 animals used for each treatment, no differences could be confirmed at a significance level of 0.05 .

\section{Continuous Milking Compared with a 56-d DP and Twice Daily Milking During Lactation}

Milk Yield. Yield of ECM from CM cows averaged $21.2 \pm 1.5 \mathrm{~kg} / \mathrm{d}$ during the last 8 wk before calving. For 1 cow, however, milk yield decreased to less than $3 \mathrm{~kg} / \mathrm{d}$ in the last week before calving. Two cows developed clinical mastitis at $\mathrm{d}-7$ and -5 and dried off independently at $\mathrm{d}-2$ relative to calving. That contrasts with the observation that up to $50 \%$ of all cows assigned to CM dry off between 7 and $2 \mathrm{~d}$ prepartum (Andersen et al., 2005; Madsen et al., 2008).
In our study, the 305-d lactation ECM yield was $17 \%$ lower in CM cows compared with $\mathrm{C}$ cows. This result was comparable with the depression in milk yield systematically entailed by the omission of the DP, as described in the literature (Swanson, 1965; Farries and Hoheisel, 1989; Rémond et al., 1992). Rémond et al. (1997) assumed that high-producing cows are less sensitive to this management system compared with lower producing cows. Our results using cows of high genetic merit did not confirm this hypothesis. This result is in accordance with Andersen et al. (2005). In fact, involution, proliferation, and differentiation of mammary parenchyma during DP represent decisive preconditions for a high subsequent lactation yield (Capuco et al., 1997) independently of the genetic merit of the cow (Smith et al., 1966; Andersen et al., 2005). Accordingly, continuously milking over more than 2 successive lactations reveals more severe production losses (18-29\%) in the subsequent lactation (Rémond et al., 1997). The depression of milk yield is caused primarily by an impaired functionality of mammary parenchyma (Annen et al., 2004).

Effects of Continuous Milking on Metabolic Profile. Glucose is a key molecule in ruminant metabolism (e.g., in lactogenesis; Guinard-Flament et al., 2006). Blood glucose concentration reflects the balance between glucose input and output. Hypoglycemia is prevented under physiologic conditions by the effects of different hormones including glucagon, catecholamines, glucocorticoids, and the GH-IGF-I system. In our study, $47 \%$ of serum samples collected between wh 1 and 4 from $\mathrm{C}$ cows revealed hypoglycemia $(<3.0 \mathrm{mmol} / \mathrm{L}$; Table 7). In contrast, only $14 \%$ of samples of CM cows collected from wk 1 to 4 revealed hypoglycemia (Table 7). The sustained physiological serum glucose levels in early lactation for CM cows indicate a more stable metabolic status and lower blood serum NEFA concentrations. Similar results were reported by Rastani et al. (2007) during the first week of lactation and by Andersen et al. (2005) and Madsen et al. (2008) during the first $5 \mathrm{wk}$ of lactation for CM cows compared with $\mathrm{C}$ cows milked twice daily after a 56-d DP. Because higher NEFA serum concentrations of $\mathrm{C}$ cows reflect a higher rate of lipolysis in adipose tissue (Mashek and Grummer, 2003), continuous milking is accompanied by reduced lipomobilization in fresh parturient cows. Simultaneously, serum BHBA concentrations were higher in $\mathrm{C}$ cows compared with $\mathrm{CM}$ cows because, in case of large amounts of NEFA entering the hepatocytes, ketogenesis represents an alternative metabolic pathway in hepatic mitochondria (Heitmann and Fernandez, 1986). Differences in serum concentration of glucose and BHBA suggest an improved metabolic status for $\mathrm{CM}$ cows in early lactation. 
The DMI of CM cows was found to be similar (Andersen et al., 2005) or even higher (Rastani et al., 2005) compared with 56-d dry cows. Usually, DP includes diet changes associated with facility and grouping changes. These management changes may contribute to a reduction of DMI. Feeding the same diet throughout the entire lactation-gestation cycle may reduce nutritional stress because of less frequent dietary changes at prepartum and may improve energy status in cows with short or no DP. Further on, lower postpartum milk yield of CM cows may contribute to reduced metabolic stress.

Effects of Continuous Milking on Milk Yield, Milk Composition, and Body Condition. The present study indicated an increased lactational milk protein concentration in CM cows $(3.91 \pm 0.28 \%)$ compared with $\mathrm{C}$ cows $(3.52 \pm 0.3 \%)$ in agreement with earlier results (Rémond et al., 2004). This difference was apparent throughout the entire lactation as indicated by an average milk protein content of more than $4.0 \%$ for the last 6 wh of lactation in CM cows. The increased milk protein content in early lactation indicates improved availability of energy attributable to a reduced milk yield (Rémond et al., 1997) because milk protein content is considered an indicator for energy supply in a herd monitoring system. It is indeed well established that improvement in the energy balance increases the protein content of milk. Regarding the total produced protein yield, CM cows produced about $25 \mathrm{~kg}$ more milk protein than $\mathrm{C}$ cows because of being milked in late pregnancy. During this time, while $\mathrm{C}$ and ODM cows were dried off, CM cows produced about 42 $\mathrm{kg}$ of milk protein. In addition to the high milk protein content throughout lactation, cows of this group produced the highest lactational milk protein yield from $\mathrm{d}$ 56 before parturition to the end of lactation.

However, the quality of the colostrum is poor in continuously milked goats (Caja et al., 2006) and cows (Annen et al., 2004) because an accumulation of immunoglobulin level requires prolonged secretion in the mammary gland before calving (Wheelock et al., 1965). Furthermore, there is concern about higher SCC levels in milk of CM cows because SCC was increased in late pregnancy for CM cows, particularly the last week before calving (Farries and Hoheisel, 1989; Rémond et al., 1992). In our study, SCC of CM cows did not differ from that of $\mathrm{C}$ cows in either early lactation or during the entire lactation. There were 2 cows with mastitis at $\mathrm{d}-7$ and -1 relative to calving; this may have been caused by the very low milk yield for these cows $(<2$ $\mathrm{kg} / \mathrm{d}$ ) followed by a lack of intramammary pressure, longer stripping times, and, as a consequence, a higher risk for mastitis for these cows, which are known to be immunosuppressed before and after calving.
In late pregnancy, the milk was progressively enriched with fat and protein, as found by Wheelock et al. (1965) and Rémond and Bonnefoy (1997). Postpartum milk fat concentration was lower for CM cows compared with C cows for the first $5 \mathrm{wk}$ of lactation. This is in contrast with Rastani et al. (2005), who observed that milk fat percentage increased from 3.86 to $4.08 \%$ when DP was reduced from 56 to $28 \mathrm{~d}$. The higher milk fat content of C cows in our study may have been caused by a higher infiltration of long-chain fatty acids from blood into milk fat, as found for periparturient cows with a strong lipolysis (Bauman et al., 2006).

The moderate decrease of BCS and backfat in CM cows in early lactation may be the consequence of an improved metabolic status for these cows as indicated by higher glucose, lower BHBA and NEFA concentrations, and higher milk protein content. The $\mathrm{C}$ cows, on the other hand, started into early lactation with a BCS of more than 3.5. Thus, these cows seemed to have been overfed during the DP, which is a well-known explanation for postpartum depression of appetite causing stronger lipolysis and proteolysis. The resulting sharp decrease of backfat and BCS was clearly recognizable in $\mathrm{C}$ cows (Figure 3 ).

\section{Once Daily Milking During the First 4 Wk of Lactation Compared with a 56-d DP and Twice Daily Milking During Lactation}

Our approach to implementing once daily milking was to improve the metabolic situation of high-yielding dairy cows after calving in a high-cost, high-return production system. This is contrast to most other studies testing the effects of once daily milking that focus on the implementation of once daily milking to improve quality of life of the farmer or as a tool to increase labor productivity, for example, in low-cost, low-return dairy systems in New Zealand (Clark et al., 2006). Few studies exist in which once daily milking was implemented during early lactation (Carruthers and Davis, 1993; Stelwagen and Knight, 1997). Interestingly, high-producing cows do not necessarily exhibit greater reductions of milk yield because of once daily milking compared with substandard cows (Davis et al., 1999). During once daily milking compared with twice daily milking, a reduction in milk yield of $19 \%$ on average is well established (Davis et al., 1999).

Only 1 recent study compared the effects of once daily milking with thrice daily milking on the energy status of the dairy cow in early lactation (Patton et al., 2006). In that study, however, the production level was much lower compared with that of the high-yielding dairy cows used in our trial. 
Effects of Once Daily Milking on Metabolism and Body Condition. Interestingly, in the study presented here, once daily milking had almost similar effects as continuous milking on metabolism and productivity in the subsequent lactation, but the effects were obviously attributable to different causes. The blood concentrations of metabolic key parameters did not differ during the first 4 wk of lactation from those of $\mathrm{CM}$ cows but were lower compared with $\mathrm{C}$ cows. In particular, the decrease of serum glucose concentration at wk 2 observed in $\mathrm{C}$ cows was not observed in ODM cows (Figure 2D). The higher blood serum glucose concentrations for ODM cows indicated less severe metabolic stress compared with those of $\mathrm{C}$ cows. The results are in agreement with previous studies that demonstrated that once daily milking for about $4 \mathrm{wk}$ in early lactation results in reduced milk yield and less metabolic stress (Davis et al., 1999). At calving, ODM cows had blood NEFA concentrations more than twice as high as CM cows. At this time, ODM cows are in practically the same metabolic situation as C cows. However, just 1 wk after calving, ODM cows had higher blood glucose concentrations and lower NEFA and BHBA blood concentrations compared with $\mathrm{C}$ cows. The ODM cows lost less body reserves during early lactation than reported elsewhere (Rémond et al., 2002). Even after switching to twice daily milking starting at wk 5 of lactation, body weight loss in the subsequent months was less pronounced in ODM cows compared with C and CM cows. Rémond et al. (2004) found that $\mathrm{BW}$ and BCS of cows milked once daily were gradually improved compared with those of cows milked twice daily at wk 36 of lactation.

Effects of Once Daily Milking on Animal Welfare and Health. Animal well-being during once daily milking in fresh cows is an important issue. Generally, it is observed that high-yielding dairy cows wait near the milking parlor before milking time and seem to expect milking, probably because of high intramammary pressure. In our study, however, we did not observe in ODM cows any indicators revealing severe discomfort, a finding in agreement with other research (Davis et al., 1999; Rémond et al., 2004; Tucker et al., 2007). One of the 12 cows mooed and lowed during the first few days of once daily milking treatment before and during afternoon milking, but after $3 \mathrm{~d}$ the animal accepted once daily milking without problems. There were 2 leaking cows in this group; 1 leaked because of teat damage. A typical concern in respect to once daily milking is udder health because udder distension in cows milked once daily may lead to a higher probability of inflammatory responses. One study indicated a doubled SCC in comparison with twice daily milking when cows were milked once daily for a longer time (Lacy-Hulbert et al., 2005). However, no differences were obvious in the incidence of mastitis for ODM cows compared with $\mathrm{C}$ or CM cows in our study, which corresponded with others (Clark et al., 2006). Rémond et al. (2004) found no differences in mean SCC between once and twice daily milking despite a sharp increase noted for cows milked once daily during the last third of lactation. Loiselle et al. (2009) found differences neither for SCC nor for chemotaxis, phagocytosis, or oxidative burst activity during once daily milking in the first week postpartum compared with twice daily milking or thereafter up to wk 14 of lactation.

Despite the similar body condition of ODM and C cows at calving, ODM cows lost less body reserves at the onset of lactation (Figure 3B) than did C cows. The improved nutritional and metabolic condition status of ODM cows is also reflected by a lower frequency of hypoglycemia during the first 4 wk of lactation compared with $\mathrm{C}$ cows.

Effects of Once Daily Milking on Productivity. The obvious reduction of total lactation ECM yield by $16 \%$ for ODM cows compared with $\mathrm{C}$ cows was primarily attributable to the reduced yield during the first 4 wk of lactation, with a smaller carryover effect after resumption of twice daily milking during the following 4 wk. Losses reported in previous experiments ranged from 7 to $34 \%$ for once daily milking experiments, with an average yield loss of about 19\% (Davis et al., 1999; Tucker et al., 2007). Rémond et al. (2004) found a reduction of total 305-d lactation milk yield of about $30 \%$ for cows milked once daily compared with those milked twice daily throughout a 305-d lactation. This reduction of milk yield may be caused by functional changes in the mammary gland: mammary cell number and metabolic activity, tight junction permeability, regulation of alveolar cell activity by feedback inhibitor of lactation, and apoptosis stimulating factors. Because these processes are essential to the proper functioning of the mammary gland, it has been suggested that milking frequency affects secretory alveolar cell activity (Vetharaniam et al., 2003) as epithelial cells begin to regress after a variable period of time and are more likely to senesce when longer intermilking intervals are imposed (Capuco et al., 2003). Changes in mammary cell activity are often measured as changes in the mRNA level and the activity of several key mammary enzymes. Furthermore, the reduced milk yield of ODM cows may be caused by a reduced alveolar capacity provoked by longer intermilking intervals (Davis et al., 1998). The effects of increasing and decreasing milking frequency on functionality of the mammary gland are excellently reviewed by Stelwagen (2001). Interestingly, 
SCC was not affected by once daily milking compared with twice daily milking in $\mathrm{C}$ cows, in accordance with earlier reports (Rémond et al., 2004).

The lactation curve of ODM cows was remarkable compared with $\mathrm{C}$ cows in respect to a reduced peak yield, a 6-wk-delayed time of peak yield, and a better persistency throughout the remainder of lactation. This is exactly the lactation curve that is favorable for dairy farmers but difficult to achieve by breeding programs (Togashi and Lin, 2003; Togashi and Lin, 2004). Persistent cows are more desirable because they are more efficient in roughage usage and suffer less metabolic stress because of high peak yield, and thus are more resilient to production diseases (Jakobsen et al., 2002). This may be attributable to the fact that the risk for metabolic disturbances depends largely on the increase of milk yield during the first weeks of lactation (Drackley, 1999). Lower NEFA and BHBA concentrations combined with a later peak yield and a better persistency revoke the reduced milk production in early lactation.

Besides milk yield, milk protein content is a matter of growing economic interest to the dairy processing industry compared with all other milk components. It must be emphasized that continuous milking as well as once daily milking are useful tools for producing milk with higher milk protein content and a higher price compared with traditional management of dairy cows. Also, Patton et al. (2006) demonstrated a higher milk protein concentration (3.55\%) and milk fat concentration $(4.70 \%)$ during the first $28 \mathrm{~d}$ of lactation for cows milked once daily compared with cows milked thrice daily. In our study, once daily milking was associated with the highest fat concentration during the first 4 wk of lactation. Because of the lower milk yield, ODM cows produced only three-fourths of the daily fat yield produced by $\mathrm{C}$ cows. However, no changes in milk protein concentration were found in short-term studies (once daily milking for $1 \mathrm{wk}$; Guinard-Flament et al., 2007; Loiselle et al., 2009).

Comparisons Between Continuous Milking and Once Daily Milking. Both once daily milking and continuous milking exhibited profound effects on metabolism and productivity. For both treatments, an improved metabolic status in early lactation was obvious as indicated by a reduced incidence of hypoglycemia and lipomobilization. Extent of reduced lactational milk yield was comparable for both treatments.

Once daily milking is furthermore a management system often chosen in pasture-based, low-cost, low-return farming systems. There are many economical aspects and lifestyle choices involved in the choice of milking frequency because certain fixed costs are associated with milking, including consumables and power. Our results indicate that once daily milking is furthermore appropriate in high-yielding dairy cows. In contrast, the additional milk produced during the extra $56 \mathrm{~d}$ in the previous lactation for the CM cows (about 1,200 $\mathrm{kg}$ ) and the higher milk protein yield compared with prepartum dried-off $\mathrm{C}$ cows added additional value to this management scheme, whereas problems related to the colostral supply of calves had a negative effect. In the present study, continuous milking was conducted during 1 gestation-lactation cycle. This approach is not practical for consecutive lactations because most cows dry off independently after more than 2 successive lactations without a DP (Rémond et al., 1997). The well-known challenges of maintaining health and wellbeing in high-yielding dairy cattle suggest that there may be management alternatives to a $56-\mathrm{d}$ DP and twice daily milking.

\section{CONCLUSIONS}

The rapid increase of milk yield after calving represents an important risk factor for metabolic disturbances in conventionally reared, high-yielding dairy cows after a 56-d DP. Both continuous milking without DP and once daily milking during the first 4 wk of lactation represent management strategies to successfully reduce the metabolic stress in fresh cows, combined with an improved metabolic balance and increased milk protein content throughout the entire lactation. The lactational ECM yield (305 d) was decreased, however, in both the ODM and CM cows by roughly $20 \%$ compared with C cows. The proportions of hypoglycemic and ketotic cows were lower in the CM group than in the C and ODM groups. The lactation curve for ODM cows peaked later and proceeded flatter. The optimal duration of once daily milking in high-yielding dairy cows remains an issue for further investigation. Milk protein content was markedly increased in $\mathrm{CM}$ cows $(+0.5 \%)$ and, to a lesser extent, in ODM cows $(+0.3 \%)$. Thus, considering the actual pricing system for milk, continuous milking and once daily milking may be meaningful, economical alternatives for dairy farmers.

\section{ACKNOWLEDGMENTS}

The authors express their appreciation to Sachsenmilch AG (Leppersdorf, Germany) and Bayerisches Staatsministerium für Ernährung, Landwirtschaft und Forsten (Munich, Germany) for financial support. We thank the farm crew for their help during study and the laboratory technicians and students for analysis of samples. For proofreading the manuscript, we thank J. Hodges (speaker at the IAEA-FAO conference, Vienna, 2009). 


\section{REFERENCES}

Andersen, J. B., T. G. Madsen, T. Larsen, K. L. Ingvartsen, and M. O. Nielsen. 2005. The effects of dry period versus continuous lactation on metabolic status and performance in periparturient cows. J. Dairy Sci. 88:3530-3541.

Annen, E. L., R. J. Collier, M. A. McGuire, and J. L. Vicini. 2004. Effects of dry period length on milk yield and mammary epithelial cells. J. Dairy Sci. 87:E66-E76.

Bauman, D. E., I. H. Mather, R. J. Wall, and A. L. Lock. 2006. Major advances associated with the biosynthesis of milk. J. Dairy Sci. 89:1235-1243.

Caja, G., A. A. Salama, and X. Such. 2006. Omitting the dry-off period negatively affects colostrum and milk yield in dairy goats. J. Dairy Sci. 89:4220-4228.

Capuco, A. V., R. M. Akers, and J. J. Smith. 1997. Mammary growth in Holstein cows during the dry period: Quantification of nucleic acids and histology. J. Dairy Sci. 80:477-487.

Capuco, A. V., S. E. Ellis, S. A. Hale, E. Long, R. A. Erdman, X. Zhao, and M. J. Paape. 2003. Lactation persistency: Insights from mammary cell proliferation studies. J. Anim. Sci. 81(Suppl. 3):18-31.

Carruthers, V. R., and S. R. C. P. J. A. Davis. 1993. Response of Jersey and Friesian cows to once a day milking and prediction of response based on udder characteristics and milk composition. J. Dairy Res. 60:13-18.

Clark, D. A., C. V. Phyn, M. J. Tong, S. J. Collis, and D. E. Dalley. 2006. A systems comparison of once- versus twice-daily milking of pastured dairy cows. J. Dairy Sci. 89:1854-1862.

Coppock, C. E., R. W. Everett, R. P. Natzke, and H. R. Ainslie. 1974. Effect of dry period length on Holstein milk production and selected disorders at parturition. J. Dairy Sci. 57:712-718.

Davis, S. R., V. C. Farr, P. J. Copeman, V. R. Carruthers, C. H. Knight, and K. Stelwagen. 1998. Partitioning of milk accumulation between cisternal and alveolar compartments of the bovine udder: Relationship to production loss during once daily milking. J. Dairy Res. 65:1-8.

Davis, S. R., V. C. Farr, and K. Stelwagen. 1999. Regulation of yield loss and milk composition during once-daily milking: A review. Livest. Prod. Sci. 59:77-94.

Distl, O. 1991. Epidemiologic and genetic analysis of veterinary data of German Brown cattle. Tierärztl. Wochenschr. 104:375-383.

Drackley, J. K. 1999. ADSA Foundation Scholar Award. Biology of dairy cows during the transition period: The final frontier? J. Dairy Sci. 82:2259-2273.

Edmonson, A. J., I. J. Lean, L. D. Weaver, T. Farver, and G. Webster. 1989. A body condition scoring chart for Holstein dairy cows. J. Dairy Sci. 72:68-78.

Farries, E., and S. Hoheisel. 1989. The influence of reduced dry periods on some performance and metabolism traits in dairy cows. J. Dairy Sci. 72(Suppl. 1):565. (Abstr.)

Fischer, B., H. Mäurer, T. Engelhard, and W. Haacker. 2002. Feed intake and energy supplementation of far-off dry cows. Veterinarija ir Zootechnika 19:41-48.

GfE. 2007. Empfehlungen zur Energie und Nährstoffversorgung der Milchkühe und Aufzuchtrinder. Ausschuss für Bedarfsnormen der Gesellschaft für Ernährungsphysiologie, Frankfurt, Germany.

Grant, R. J., and J. L. Albright. 1995. Feeding behavior and management factors during the transition period in dairy cattle. J. Anim. Sci. 73:2791-2803.

Grummer, R. R., D. G. Mashek, and A. Hayirli. 2004. Dry matter intake and energy balance in the transition period. Vet. Clin. North Am. Food Anim. Pract. 20:447-470.

Grummer, R. R., and R. R. Rastani. 2004. Why reevaluate dry period length? J. Dairy Sci. 87:E77-E85.

Guinard-Flament, J., E. Delamaire, P. Lamberton, and J. L. Peyraud. 2007. Adaptations of mammary uptake and nutrient use to oncedaily milking and feed restriction in dairy cows. J. Dairy Sci. 90:5062-5072.

Guinard-Flament, J., E. Delamaire, S. Lemosquet, M. Boutinaud, and Y. David. 2006. Changes in mammary uptake and metabolic fate of glucose with once-daily milking and feed restriction in dairy cows. Reprod. Nutr. Dev. 46:589-598.

Gulay, M. S., M. J. Hayen, K. C. Bachman, T. Belloso, M. Liboni, and H. H. Head. 2003. Milk production and feed intake of Holstein cows given short (30-d) or normal (60-d) dry periods. J. Dairy Sci. 86:2030-2038.

Heitmann, R. N., and J. M. Fernandez. 1986. Autoregulation of alimentary and hepatic ketogenesis in sheep. J. Dairy Sci. 69:1270-1281.

Ingvartsen, K. L., and J. B. Andersen. 2000. Integration of metabolism and intake regulation: A review focusing on periparturient animals. J. Dairy Sci. 83:1573-1597.

Ingvartsen, K. L., R. J. Dewhurst, and N. C. Friggens. 2003. On the relationship between lactational performance and health: Is it yield or metabolic imbalance that cause production diseases in dairy cattle? Livest. Prod. Sci. 83:277-308.

Jakobsen, J. H., P. Madsen, J. Jensen, J. Pedersen, L. G. Christensen, and D. A. Sorensen. 2002. Genetic parameters for milk production and persistency for Danish Holsteins estimated in random regression models using REML. J. Dairy Sci. 85:1607-1616.

Jandrassik, J., and P. Grof. 1938. Quantitative determination of total and direct bilirubin in serum and plasma. Biochem. Z. 297:8189.

Lacy-Hulbert, S. J., D. E. Dalley, and D. A. Clark. 2005. The effects of once a day milking on mastitis and somatic cell count. Pages 137-142 in Proc. N.Z. Soc. Anim. Prod., Hamilton, New Zealand. Jopson, NB, Dunedin, New Zealand.

Lee, A. J., and J. Wardrop. 1984. Predicting daily milk yield, fat percent, and protein percent from morning or afternoon tests. J. Dairy Sci. 67:351-360.

Littell, R. C., P. R. Henry, and C. B. Ammerman. 1998. Statistical analysis of repeated measures data using SAS procedures. J. Anim. Sci. 76:1216-1231.

Loiselle, M. C., C. Ster, B. G. Talbot, X. Zhao, G. F. Wagner, Y. R. Boisclair, and P. Lacasse. 2009. Impact of postpartum milking frequency on the immune system and the blood metabolite concentration of dairy cows. J. Dairy Sci. 92:1900-1912.

Macrae, A. I., D. A. Whitaker, E. Bourrough, A. Dowell, and J. M. Kelly. 2006. Use of metabolic profiles for the assessment of dietary adequacy in UK dairy herds. Vet. Rec. 159:655-661.

Madsen, T. G., M. O. Nielsen, J. B. Andersen, and K. L. Ingvartsen. 2008. Continuous lactation in dairy cows: Effect on milk production and mammary nutrient supply and extraction. J. Dairy Sci. 91:1791-1801.

Mashek, D. G., and R. R. Grummer. 2003. Effects of long chain fatty acids on lipid and glucose metabolism in monolayer cultures of bovine hepatocytes. J. Dairy Sci. 86:2390-2396.

Mulligan, F. J., and M. L. Doherty. 2008. Production diseases of the transition cow. Vet. J. 176:3-9.

O'Connor, J. J. Jr., and P. A. Oltenacu. 1988. Determination of optimum drying off time for dairy cows using decision analysis and computer simulation. J. Dairy Sci. 71:3080-3091.

Patton, J., D. A. Kenny, J. F. Mee, F. P. O'Mara, D. C. Wathes, M. Cook, and J. J. Murphy. 2006. Effect of milking frequency and diet on milk production, energy balance, and reproduction in dairy cows. J. Dairy Sci. 89:1478-1487.

Pezeshki, A., J. Mehrzad, G. R. Ghorbani, B. De Spiegeleer, R. J. Collier, and C. Burvenich. 2008. The effect of dry period length reduction to 28 days on the performance of multiparous dairy cows in the subsequent lactation. Can. J. Anim. Sci. 88:449-456.

Pezeshki, A., J. Mehrzad, G. R. Ghorbani, H. R. Rahmani, R. J. Collier, and C. Burvenich. 2007. Effects of short dry periods on performance and metabolic status in Holstein dairy cows. J. Dairy Sci. 90:5531-5541.

Rastani, R. R., N. S. Del Rio, T. F. Gressley, G. E. Dahl, and R. R. Grummer. 2007. Effects of increasing milking frequency during the last 28 days of gestation on milk production, dry matter intake, and energy balance in dairy cows. J. Dairy Sci. 90:1729-1739.

Rastani, R. R., R. R. Grummer, S. J. Bertics, A. Gumen, M. C. Wiltbank, D. G. Mashek, and M. C. Schwab. 2005. Reducing dry period length to simplify feeding transition cows: Milk production, 
energy balance, and metabolic profiles. J. Dairy Sci. 88:10041014.

Rauw, W. M., E. Kanis, and E. N. G. F. J. Noordhuizen-Stassen. 1998. Undesiderable side effects of selection for high production efficiency in farm animals: A review. Livest. Prod. Sci. 56:15-33.

Reist, M., D. K. Erdin, E. D. von Euw, K. M. Tschümperlin, H. Leuenberger, H. M. Hammon, C. Morel, C. Philipona, Y. Zbinden, N. Künzi, and J. W. Blum. 2003. Postpartum reproductive function: Association with energy, metabolic and endocrine status in high yielding dairy cows. Theriogenology 59:1707-1723.

Rémond, B., S. Aubailly, Y. Chilliard, D. Dupont, D. Pomies, and M. Petit. 2002. Combined effects of once-daily milking and feeding level in the first three weeks of lactation on milk production and enzyme activities, and nutritional status, Holstein cows. Anim. Res. 51:101-117.

Rémond, B., and J. C. Bonnefoy. 1997. Performance of a herd of Holstein cows managed without the dry period. Ann. Zootech. $46: 3-12$.

Rémond, B., A. Ollier, and G. Miranda. 1992. Milking of cows in late pregnancy: Milk production during this period and during the succeeding lactation. J. Dairy Res. 59:233-241.

Rémond, B., D. Pomiès, D. Dupont, and Y. Chilliard. 2004. Once-aday milking of multiparous Holstein cows throughout the entire lactation: Milk yield and composition, and nutritional status. Anim. Res. 53:201-212.

Rémond, B., J. Rouel, N. Pinson, and S. Jabet. 1997. An attempt to omit the dry period over three consecutive lactations in dairy cows. Ann. Zootech. 46:399-408.

SAS Institute. 2002. SAS/STAT User's Guide. Version 9.1. SAS Institute Inc., Cary, NC.

Schaeffer, L. R., and C. R. Henderson. 1972. Effects of days dry and days open on Holstein milk production. J. Dairy Sci. 55:107112.

Schröder, U. J., and R. Staufenbiel. 2006. Invited review: Methods to determine body fat reserves in the dairy cow with special regard to ultrasonographic measurement of backfat thickness. J. Dairy Sci. 89:1-14.
Smith, A., J. V. Wheelock, and F. H. Dodd. 1966. Effect of milking throughout pregnancy on milk yield in the succeeding lactation. J. Dairy Sci. 49:895-896.

Stelwagen, K. 2001. Effect of milking frequency on mammary functioning and shape of the lactation curve. J. Dairy Sci. 84:E204-E211.

Stelwagen, K., and C. H. Knight. 1997. Effect of unilateral once or twice daily milking of cows on milk yield and udder characteristics in early and late lactation. J. Dairy Res. 64:487-494.

Swanson, E. W. 1965. Comparing continuous milking with sixty-day dry periods in successive lactations. J. Dairy Sci. 48:1205-1209.

Togashi, K., and C. Y. Lin. 2003. Modifying the lactation curve to improve lactation milk and persistency. J. Dairy Sci. 86:14871493.

Togashi, K., and C. Y. Lin. 2004. Efficiency of different selection criteria for persistency and lactation milk yield. J. Dairy Sci. $87: 1528-1535$.

Tucker, C. B., D. E. Dalley, J. L. Burke, and D. A. Clark. 2007. Milking cows once daily influences behavior and udder firmness at peak and mid lactation. J. Dairy Sci. 90:1692-1703.

van der Iest, R., and J. E. Hillerton. 1989. Short-term effects of frequent milking of dairy cows. J. Dairy Res. 56:587-592.

Vetharaniam, I., S. R. Davis, T. K. Soboleva, P. R. Shorten, and G. C. Wake. 2003. Modeling the interaction of milking frequency and nutrition on mammary gland growth and lactation. J. Dairy Sci. 86:1987-1996.

Wall, E. H., and T. B. McFadden. 2008. Use it or lose it: Enhancing milk production efficiency by frequent milking of dairy cows. J. Anim. Sci. 86:27-36.

Wheelock, J. V., J. A. F. Rook, and F. H. Dodd. 1965. The effect of milking throughout the whole pregnancy on the composition of cow's milk. J. Dairy Res. 32:249-254.

Wilde, C. J., C. V. Addey, P. Li, and D. G. Fernig. 1997. Programmed cell death in bovine mammary tissue during lactation and involution. Exp. Physiol. 82:943-953. 